\title{
Fish passages in South America: an overview of studied facilities and research effort
}

\author{
Nibelle A. Lira', Paulo S. Pompeu², Carlos S. Agostinho ${ }^{3}$, Angelo A. Agostinho ${ }^{4}$, \\ Marlene Sofia Arcifa ${ }^{5}$ and Fernando M. Pelicice ${ }^{3}$
}

River regulation has fragmented fluvial ecosystems in South America, affecting fish migration and dispersion dynamics. In response, authorities have installed fish passage facilities (FPF) to mitigate impacts. However, little is known about the geographical distribution of these facilities, and no synthesis of the research effort applied to understanding their functioning and limitations exists. To address this issue, our study gathered the available scientific literature about fishways in South America to provide an overview of studied FPF and associated research effort. We found 80 studies that investigated 25 FPF, mostly ladders installed in the upper reaches of large rivers, particularly in the Paraná River Basin. One important finding is that most facilities do not lead to upstream and/or downstream sites due to the presence of other dams with no FPF. Though the number of studies has increased over the past 10 years, there is no consistent trend towards increased research effort. Overall, studies have focused on the fishway itself (i.e. upstream passage), and rarely evaluated broader issues (i.e. habitat distribution, population dynamics, conservation and management success). Our research therefore identified technical limitations of past studies, and revealed important gaps in the knowledge of FPF as a management tool.

Keywords: Conservation, Dam, Fishway, Impact, Management.

A implantação de barragens tem perturbado e fragmentado os ecossistemas fluviais da América do Sul, afetando a migração dos peixes e dinâmicas de dispersão. Sistemas de transposição de peixes (STPs) têm sido instalados na tentativa de atenuar esses impactos. No entanto, pouco se sabe sobre a distribuição geográfica desses dispositivos, bem como o esforço de pesquisa aplicado para entender seu funcionamento e limitações. Nosso trabalho reuniu a literatura disponível com a finalidade de fornecer um panorama sobre os mecanismos investigados na América do Sul, bem como revelar o esforço e perfil das pesquisas. Encontramos 80 estudos que investigaram 25 STPs, a maioria escadas instaladas nos trechos superiores de grandes rios, particularmente na bacia do rio Paraná. Um resultado interessante é que a maior parte dos STPs está desconectada de trechos a montante e jusante devido à presença de outras barragens sem STPs. Embora o número de estudos tenha aumentado na última década, não registramos tendência consistente de incremento ao longo dos anos. No geral, os estudos abordam aspectos do próprio STP, especificamente a passagem ascendente, ignorando temas mais abrangentes (i.e. distribuição de habitats, dinâmica populacional). Além disso, o foco da pesquisa se direciona especialmente às questões de eficiência da passagem e raramente ao contexto da conservação e sucesso do manejo. Nossa avaliação, portanto, indicou que os estudos pretéritos são tecnicamente limitados, revelando importantes lacunas sobre o conhecimento dos STPs como medida de manejo.

Palavras-chave: Barragens, Conservação, Gestão, Impacto, Passagens de peixes.

\section{Introduction}

River regulation has significantly disrupted fluvial ecosystems in South America (Agostinho et al., 2016). This process caused severe changes in the natural flow regime and habitat availability, with implications for the abundance of aquatic organisms and community structure. Migratory fishes are particularly affected by river damming, because dams and large impoundments interrupt migration routes (Agostinho et al., 2007a; Antonio et al., 2007; Pelicice et al., 2015) and cause the loss of spawning sites and nursery areas (Pelicice, Agostinho, 2008). The current decline of migratory fishes, which include local extinctions, has been linked to disturbances caused by river damming (Freeman et al., 2003; Okada et al., 2005; Hoeinghaus et al., 2009; Agostinho et al., 2016).

\footnotetext{
${ }^{1}$ Programa de Pós-Graduação em Biodiversidade, Ecologia e Conservação (antigo Ecologia de Ecótonos), Universidade Federal do Tocantins, 77500-000 Porto Nacional, TO, Brazil. nibelleaires@gmail.com (corresponding author)

${ }^{2}$ Departamento de Biologia, Universidade Federal de Lavras, 37200-000 Lavras, MG, Brazil. pompeu@dbi.ufla.br

${ }^{3}$ Núcleo de Estudos Ambientais, Universidade Federal do Tocantins, Jardim dos Ipês, 77500-000 Porto Nacional, TO, Brazil. (CSA) agostinhocs@gmail.com, (FMP) fmpelicice@gmail.com

${ }^{4}$ Núcleo de Pesquisa em Limnologia, Ictiologia e Aquicultura, Universidade Estadual de Maringá, 87020-900 Maringá, PR, Brazil. agostinhoaa@gmail.com

${ }^{5}$ Universidade de São Paulo, Departamento de Biologia, 14040-901 Ribeirão Preto, SP, Brazil. marcifa@usp.br
} 
Management actions have been proposed to mitigate these impacts. Among these initiatives, fish passage facilities (hereafter FPF) have been installed in different South American basins. Designed to reconnect river segments fragmented by dams, FPF allow, in principle, the continuity of spawning migrations by helping fish to overcome the dam (Clay, 1995). This approach was originally developed in Europe and North America, where fish ladders had relatively high success enabling the upstream migration of salmon species (Agostinho et al., 2007a). In South America, particularly in Brazil, the first FPF was installed in the beginning of the $20^{\text {th }}$ century; these devices, however, became popular in the past 50 years, when different types were installed in many basins, including lifts, locks, artificial canals and ladders (Agostinho et al., 2002; Godinho, Kynard, 2008). These facilities are usually seen as efficient management actions, and received support from authorities, stakeholders and the general public. Recent studies, however, have elicited discussions about the value of FPF to foster migratory fish conservation in South America, because several aspects concerning their functioning and management role remain poorly known (e.g., Agostinho et al., 2002; Oldani et al., 2007; Pelicice, Agostinho, 2008; Pompeu et al., 2012; Pelicice et al., 2015). These studies argue that evaluations rarely preceeded or followed the construction of FPF, while monitoring programs traditionally focused on variables with partial relevance for conservation plans (e.g., upstream passage), while neglecting other important issues (e.g., population dynamics, spawning, recruitment and dispersion). Not surprisingly, important limitations have been reported, as for example, high selectivity for upstream (e.g., Agostinho et al., 2007c; Volpato et al., 2009) and downstream passage (e.g., Agostinho et al., 2007b; Agostinho et al., 2011; Suzuki et al., 2011; Pelicice, Agostinho, 2012; Britto, Carvalho, 2013). These limitations cannot be ignored, since they compromise the primary function of FPF (i.e., reestablishment of migratory movements) and may promote changes in the structure and distribution of populations at the regional level, causing additional impacts (Pelicice, Agostinho, 2008). In summary, the common assertion that FPF are efficient management tools has been challenged by studies conducted in South America (cited above) and elsewhere (McLaughlin et al., 2012; Brown et al., 2013; Kemp, 2016).

In this context, systematic analysis and review of the scientific literature devoted to FPF is needed to reveal patterns and trends in research effort, main questions and methodologies (e.g., Roscoe, Hinch, 2010). Yet, no such study has focused on South America. This information is important because recent studies (e.g., Pelicice, Agostinho, 2008; Pompeu et al., 2012) have cast doubt on the conservation value of FPF and highlighted the need to increase research effort applied to this topic. In addition, a comprehensive review can reveal knowledge gaps, improve our understanding of management success, and guide future research. For example, we know little about the number and spatial distribution of studied FPF across South America; similarly, we do not know how research effort (number and type of studies) is distributed among existing FPF. It has been suggested, for example, that most studies focus on upstream migration and neglect postpassage survival and conservation issues (e.g., Pompeu et al., 2012; Pelicice et al., 2015). A systematic literature review would provide valuable information regarding these topics. To fill that need, this study aimed to characterize studied FPF in South America, and systematically review the evidence in studies that investigated these structures. In particular, we provide an overview of studied FPF (geographical distribution, types and spatial scenarios) and describe their research effort and profile (number of studies, study type, questions and other issues).

\section{Material and Methods}

Data collection. Our study is based on past scientific research on FPF installed in South America. We conducted an extensive literature search by combining different keywords (fish, dam, fishway, passage, ladder, lift, lateral canal; in Portuguese and English) in several databases, i.e., Web of Science (www.isiknowledge.com), Scielo (www. scielo.org), Portal Capes (www.periodicos.capes.gov. br) and Google ${ }^{\circledR}$ (www.google.com.br). In addition, we complemented our survey by consulting experts in the field, personal libraries, and cross-reference search. We targeted peer-review articles published in scientific journals, but we complemented the search with theses, dissertations, book chapters and conference abstracts (including all expanded abstracts published in the proceedings of the International Symposium on Fish Passages in South America, held in Brazil in 2007 and 2012). Among the types of FPF considered were ladders, lifts, lateral canals, locks and trap-truck systems (sensu Agostinho et al., 2007a).

Fish passage overview. From each independent study, we collected information about the dam and the fish passage. Concerning the dam, we recorded the name, location, river and basin; concerning the FPF, we recorded the name, type (ladder, lift, lateral canal, lock and trap-truck), hydraulic model (for ladders) and spatial characteristics. We classified each FPF according to: (i) river type, i.e., main channel (when installed in the main stem), main tributary (when installed in tributaries that flow into the main stem, e.g., Grande, Paranapanema and Uruguay rivers) and secondary tributary (other rivers); (ii) location in the basin, i.e., upper, middle and lower reaches; and (iii) connectivity to upstream and downstream reaches, i.e., relative to the presence of other dams and FPF.

Research effort and profile. From each independent study, we recorded year of publication and year in which the study was conducted. To describe the research profile 
of each study, we collected information about study type, sampling location, passage direction, level of biotic organization and target taxon. We sorted studies into six study type categories: sampling, experiment, mark-recapture, modelling (i.e. predictive approaches), telemetry and review/synthesis. Sampling locations were also classified in three categories: those that sampled only upstream and/or downstream from the dam (surrounding), those that sampled only the FPF themselves (FPF) and those that sampled both (surrounding+FPF). Research focus on passage direction (upstream and/or downstream) was classified as upstream, downstream and upstream + downstream. The level of biotic organization addressed by each study was categorized as population (when it focused on a single species), multi-species (when it focused on several populations) or assemblage (when it considered all species). Target species from populationlevel studies were recorded and classified as Migratory and Non-migratory (sensu Agostinho et al., 2003).

We also identified the general research question of each study, following methodology proposed by Roscoe, Hinch (2010). Research questions were classified as: (i) efficiency, when it examined overall aspects (quantitative and qualitative) of fish passage at the FPF; (ii) mechanism, when the study addressed factors that affect fish passage (e.g., environmental, structural/hydraulic and/or behavioral); (iii) physiology, when the study considered endogenous or physiological consequences of the passage (e.g., energetic costs, metabolism); and (iv) consequences, when the study addressed post-passage effects other than physiological responses (e.g., reproduction success, predation, mortality, injuries).

Data analysis. To provide an overview of studied FPF in South America, we inventoried the total number of recorded facilities, calculated the percentage falling into each type, and plotted these facilities on a map. In order to investigate spatial questions, we calculated the percentage of facilities installed in each river type (main channel, main tributary or secondary tributary), location type (upper, middle and lower) and connectivity category.

To investigate research effort, we calculated the number of papers published each year, and the time interval between the beginning of the FPF operation and the date of first evaluation. To do this, we calculated the average, minimum and maximum time interval, and grouped the studies in the following classes: 0, $1-3,4-6,7-9$ and $>10$ years. The relationship between FPF age and the time elapsed before the first evaluation was tested through nonparametric Spearman Rank correlation ( $5 \%$ significance level). We also calculated the percentage of studies in each spatial scenario and research profile category, and listed all target-species (with their frequency of occurrence) investigated by population-level studies. Finally, concerning passage direction, we calculated the ratio between the number of studies focusing on downstream and upstream passage (downstream:upstream).

To determine the relative prevalence of research questions among studies, we calculated the percentage of studies in each category (efficiency, mechanism, physiology and consequence), and calculated their number in each year (1984-2014).

\section{Results}

Fish passage overview. According to our investigation, 25 FPF have been studied in different river basins in South America (Tab. 1), located mainly in the Paraná (52\%) and Amazon (12\%) basins (Fig. 1). Most are ladders (70.8\%), followed by lifts $(8.3 \%)$, lateral canals $(8.3 \%)$, trap-truck systems $(8.3 \%)$ and locks $(4.2 \%)$.

Tab. 1. Fish passage facilities in South America based on studies retrieved in our literature survey. $N=$ number of studies. Review/synthesis and modelling papers are not listed in the table. Review/Synthesis papers: Agostinho et al. (2002); Agostinho et al. (2004); Baigún et al. (2007); Godinho, Kynard (2008); Lopes, Silva (2012); Pompeu et al. (2012); Pelicice et al. (2015). Modelling papers: Duarte et al. (2012); Santos et al. (2007); Santos, Martinez (2012); Santos et al. (2012).

\begin{tabular}{|c|c|c|c|c|c|c|c|}
\hline Fish passage & Type & Type (ladder) & Dam & River & Basin & $\mathrm{N}$ & Studies \\
\hline 1) Santo Antônio & Lateral Canal & & Santo Antônio & Madeira & Amazon & 1 & Rodrigues et al. (2012) \\
\hline 2) Lajeado & Ladder & Weir and Orifice & Lajeado & Tocantins & Amazon & 5 & $\begin{array}{l}\text { Agostinho et al. (2007c); } \\
\text { Agostinho et al. (2007b); } \\
\text { Agostinho et al. (2007d); } \\
\text { Agostinho et al. (2011); } \\
\text { Agostinho et al. (2012) }\end{array}$ \\
\hline 3) Peixe Angical & Ladder & Weir and Orifice & Peixe Angical & Tocantins & Amazon & 6 & $\begin{array}{l}\text { Agostinho et al. (2009); } \\
\text { Freitas et al. (2009); Pereira- } \\
\text { Assis et al. (2009a); Pereira- } \\
\text { Assis et al. (2009b); Pereira- } \\
\text { Assis (2010); Pelicice, } \\
\text { Agostinho (2012) }\end{array}$ \\
\hline 4) Igarapé & Ladder & & Igarapé & Paraopeba & São Francisco & 2 & Alves (2007a); Alves (2012) \\
\hline
\end{tabular}


Tab. 1. (continued)

\begin{tabular}{|c|c|c|c|c|c|c|c|}
\hline Fish passage & Type & Type (ladder) & Dam & River & Basin & $\mathrm{N}$ & Studies \\
\hline 5) Santa Clara & $\begin{array}{l}\text { Lift } \\
\text { (trap) and } \\
\text { truck }\end{array}$ & & Santa Clara & Mucuri & Mucuri & 5 & $\begin{array}{l}\text { Pompeu et al. (2004); } \\
\text { Pompeu, Martinez (2005); } \\
\text { Pompeu, Martinez (2006); } \\
\text { Pompeu, Martinez (2007); } \\
\text { Pompeu et al. (2011) }\end{array}$ \\
\hline 6) Risoleta Neves & Ladder (trap) and truck & Pool \& weir & Risoleta Neves & Doce & Doce & 1 & Braga et al. (2007) \\
\hline 7) Baguari & Ladder & Vertical-slot & Baguari & Doce & Doce & 1 & Silva et al. (2012a) \\
\hline 8) Ilha dos Pombos & Ladder & & Ilha dos Pombos & Paraíba do Sul & Paraíba do Sul & 1 & Bastos et al. (2009) \\
\hline 9) Funil & Lift & & Funil & Grande & Paraná & 6 & $\begin{array}{l}\text { Alves et al. (2007b); Godinho } \\
\text { et al. (2007); Pereira, Pompeu } \\
\text { (2012); Souza et al. (2007); } \\
\text { Suzuki et al. (2011); Suzuki } \\
\text { et al. (2013) }\end{array}$ \\
\hline 10) Igarapava & Ladder & Vertical-slot & Igarapava & Grande & Paraná & 8 & $\begin{array}{l}\text { Bizzoto et al. (2009); Bowen } \\
\text { et al. (2006); Casali et } \\
\text { al.(2009); Godinho et al. } \\
\text { (2012); Maia } \text { et al. (2007); } \\
\text { Silva } \text { et al. (2012b); Vono } \\
\text { (2004); Vono et al. (2007) }\end{array}$ \\
\hline 11) Canoas I & Ladder & Weir and Orifice & Canoas I & Paranapanema & Paraná & 4 & $\begin{array}{l}\text { Britto, Carvalho (2013); } \\
\text { Lopes et al. (2007); Pelicice, } \\
\text { Agostinho (2008); Ramos et } \\
\text { al. (2012) }\end{array}$ \\
\hline 12) Canoas II & Ladder & Weir and Orifice & Canoas II & Paranapanema & Paraná & 4 & $\begin{array}{l}\text { Britto, Carvalho (2013); } \\
\text { Lopes et al. (2007); Pelicice, } \\
\text { Agostinho (2008); Ramos et } \\
\text { al. (2012) }\end{array}$ \\
\hline 13) Ourinhos & Ladder & Pool \&Weir & Ourinhos & Paranapanema & Paraná & 1 & Arcifa, Esguícero (2012) \\
\hline 14) Cachoeira das Emas & Ladder & Pool \&Weir & $\begin{array}{c}\text { Cachoeira das } \\
\text { Emas }\end{array}$ & Mogi Guassu & Paraná & 1 & Godoy (1987) \\
\hline 15) Gavião Peixoto & Ladder & & Gavião Peixoto & Jacaré-Guaçu & Paraná & 1 & Esguícero, Arcifa (2010) \\
\hline 16) Palmeiras & Ladder & Weir and Orifice & Palmeiras & Sapucaí-Mirim & Paraná & 1 & Souza et al. (2012) \\
\hline 17) Salto de Morais & Ladder & & Salto de Morais & Tijuco & Paraná & 1 & Godinho et al. (1991) \\
\hline 18) Porto-Primavera & Ladder & Weir and Orifice & Porto Primavera & Paraná & Paraná & 9 & $\begin{array}{l}\text { Antonio et al. (2007); } \\
\text { Assumpção et al. (2012); } \\
\text { Makrakis et al. (2007a); } \\
\text { Makrakis et al. (2007b); } \\
\text { Makrakis et al. (2012); } \\
\text { Pelicice, Agostinho (2008); } \\
\text { Silva et al. (2012c); Volpato et } \\
\text { al. (2009); Wagner et al. (2012) }\end{array}$ \\
\hline 19) Canal da Piracema & Lateral Canal & & Itaipu & Paraná & Paraná & 6 & $\begin{array}{l}\text { Fontes-Júnior et al. (2012a); } \\
\text { Fontes-Júnior et al. (2012b); } \\
\text { Hahn } \text { et al. (2007); Hahn } \\
\text { (2007); Makrakis et al. } \\
\text { (2007c); Makrakis et al. } \\
\text { (2010) }\end{array}$ \\
\hline 20) Escada de Itaipu & Ladder & Weir and Orifice & Itaipu & Paraná & Paraná & 4 & $\begin{array}{l}\text { Borguethi et al. (1994); } \\
\text { Fernandez et al. (2004); } \\
\text { Fernandez et al. (2007a); } \\
\text { Fernandez et al. (2007b) }\end{array}$ \\
\hline 21) Yacyreta & Lift & & Yacyretá & Paraná & Paraná & 3 & $\begin{array}{l}\text { Oldani et al. (2001); Oldani, } \\
\text { Baigún (2002); Oldani et al. } \\
(2007)\end{array}$ \\
\hline 22) Salto Grande & Lock & & Salto Grande & Uruguay & Uruguay & 1 & Oldani et al. (2007) \\
\hline 23) ETA III Ribeirão Garcia & Ladder & & ETA III & Itajaí-Açú & Itajaí & 1 & Moretto $(2005)$ \\
\hline 24) José Barasuol & Lateral Canal & & José Barasuol & Ijuí & Uruguay & 1 & Kusma, Ferreira (2009) \\
\hline 25) Rota 28 & Ladder & Pool \&Weir & Rota 28 & Pilcomayo & Pilcomayo & 1 & Baigún et al. (2012) \\
\hline
\end{tabular}




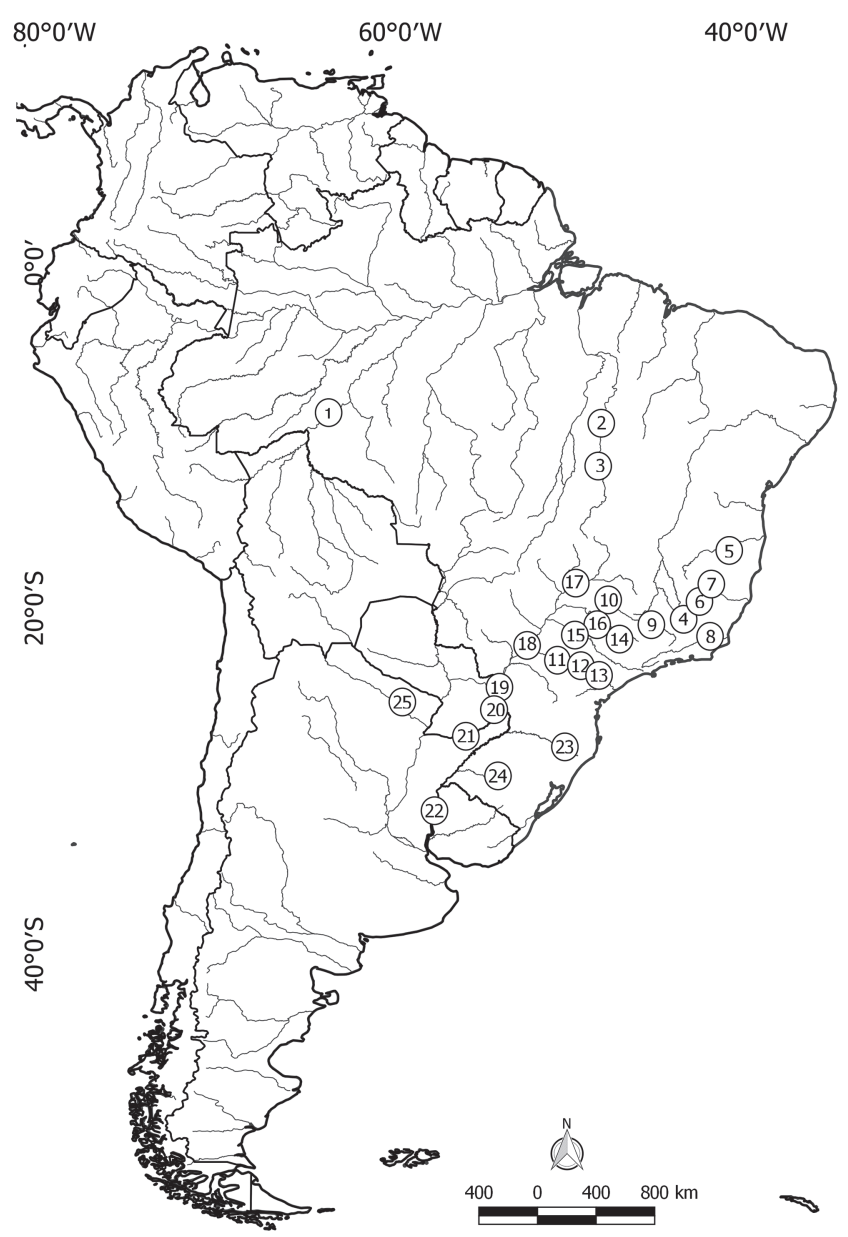

Fig. 1. Spatial distribution of fish passage facilities in South America whose function has been investigated. Identification numbers and respective studies are shown in Tab. 1.

Most FPF were installed in large rivers $(44 \%$ in the main channel and $36 \%$ in main tributaries) (Fig. 2a), and in upper reaches of the basin (Fig. 2b). We recorded eight different connectivity scenarios (Fig. 3). All studied FPF were located upstream or downstream of another dam, and $59.1 \%$ had dams in both directions. Upstream dams were present in $86.4 \%$ of the cases, being $31.8 \%$ equipped with FPF; downstream dams were present in $72.7 \%$ of the cases, being $40.9 \%$ equipped with FPF (Fig. 3). Some studied FPF are isolated in both directions $(18.2 \%)$, while some are connected (free stretch or via FPF) to both upstream and downstream reaches $(31.6 \%)$.

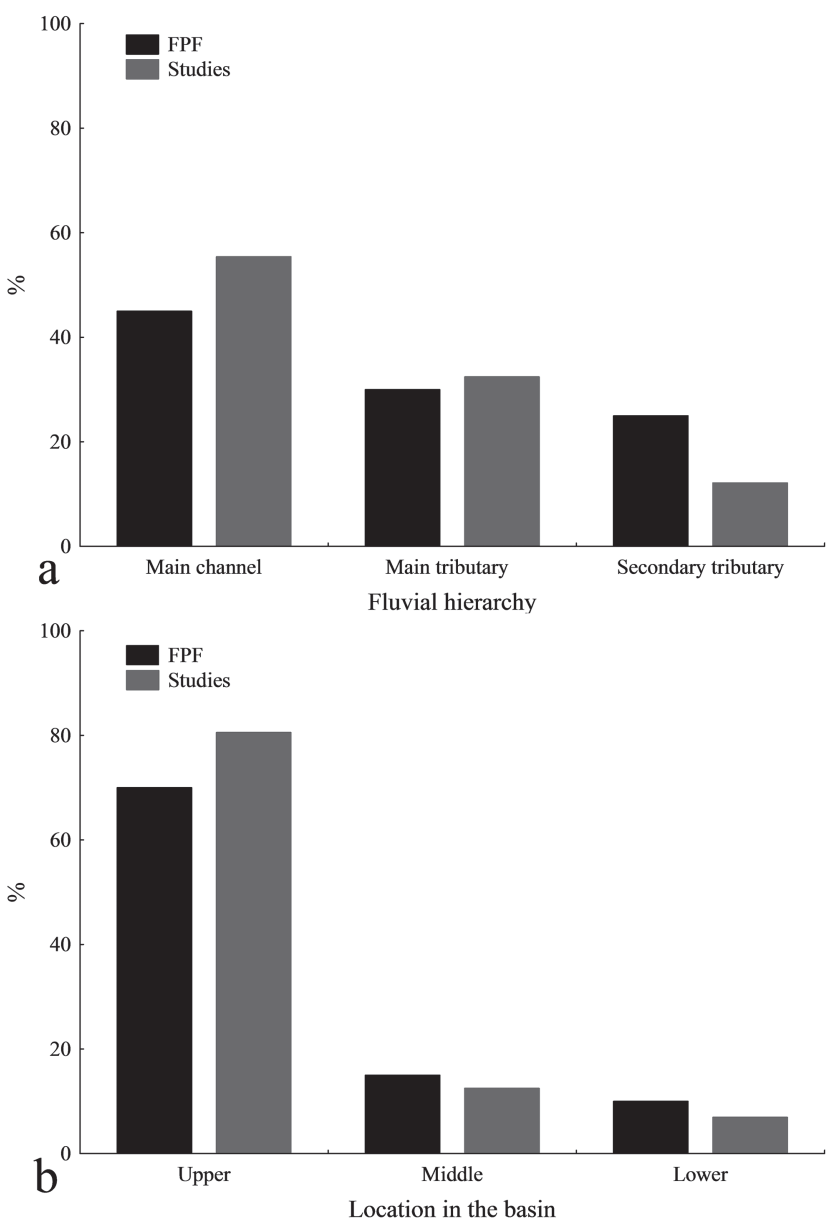

Fig. 2. Proportion of fish passage facilities (FPF) and studies in the different categories of river type and location in the basin. a. fluvial hierarchy; b. location in the basin.
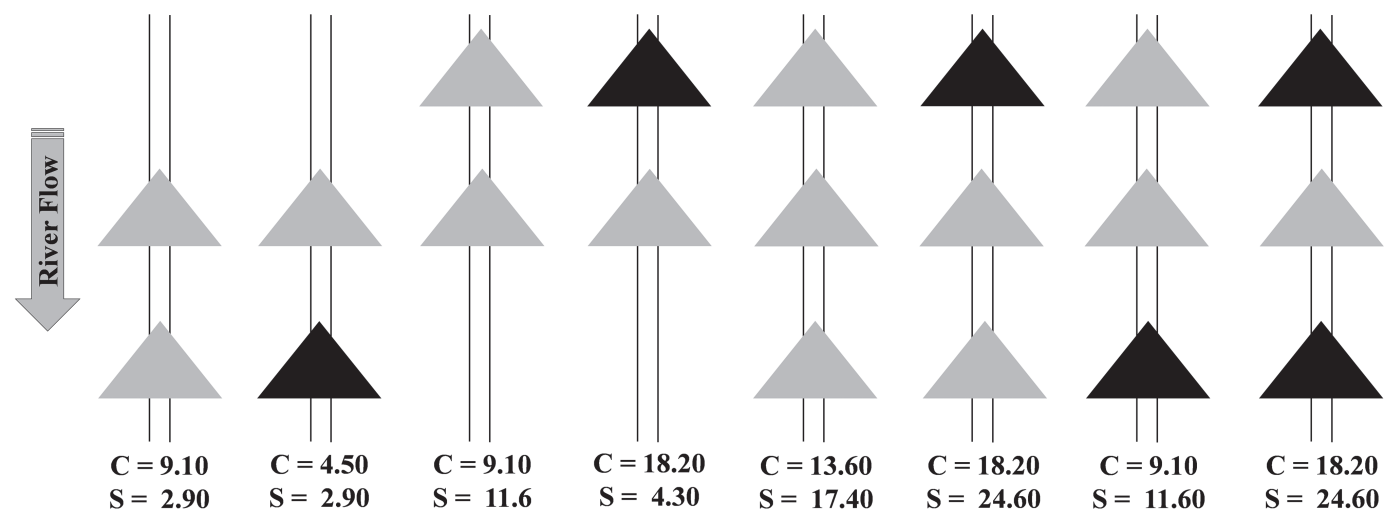

Fig. 3. Connectivity of the studied dam (middle triangle) with upstream and downstream reaches, mediated by the presence/ absence of other dams (other triangles) and fish passage facilities (black = passage absent; grey = passage present). The figure shows the percentage of each connectivity scenario (C) and studies (S). 
Research effort and profile. Our literature search retrieved 80 independent studies, including peer-reviewed articles (70\%), abstracts $(15 \%)$, book chapters $(11.2 \%)$, theses, dissertations and monographs $(3.8 \%)$. We recorded relatively few studies published in any given year, with almost all studies published in the last decade, especially in 2007 and 2012, which are the dates of the International Symposia on Fish Passages in South America (Fig. 4). Most studies investigated ladders $(68.9 \%)$, while the remaining focused on lifts $(12.2 \%)$, lateral canals $(9.5 \%)$, trap-truck systems $(8.1 \%)$ and locks $(1.4 \%)$. Passage facilities located in the Paraná and Tocantins river basins had more research effort, with 49 and 11 publications, respectively (Tab. 1).

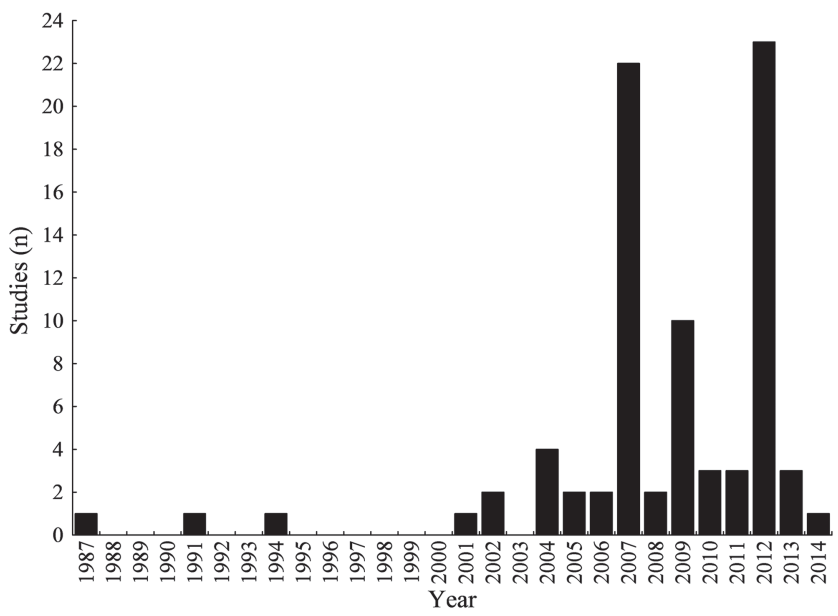

Fig. 4. Number of studies published over the years (19872014) that investigated fish passage facilities in South America.

Most studies focused on FPF installed in the main channel and main tributaries (Fig. 2a); virtually all studies were carried out in upper reaches (Fig. 2b). Concerning connectivity, most studies (78.2\%) focused on FPF located between upstream and downstream dams (Fig. 3). A total of $68 \%$ of studies investigated FPF that were disconnected from downstream $(39.1 \%)$ or upstream reaches $(53.5 \%)$; only $31.9 \%$ focused on FPF that were connected (by freely flowing stretches of river or via FPF) to both upstream and downstream reaches (Fig. 3).

Our data indicated that once some FPF started operating, their first evaluation was delayed (Fig. 5). The mean time interval to the first evaluation was 3.32 years (range: 0 to 34 years), and most FPF (69\%) were studied within 3 years of operation. The age of facilities correlated negatively with the number of years elapsed before the first evaluation (Spearman: $\mathrm{t}=-2.91 ; \mathrm{R}=0.37, \mathrm{p}=0.0052$ ), indicating that evaluation of older FPF has been delayed.

Most studies were based on sampling (55.7\%), followed by telemetry $(12.4 \%)$, mark/recapture $(10.2 \%)$, experiments (10.2\%), review/synthesis $(9.4 \%)$ and modelling (2\%) (Fig. $6 a)$. Investigations usually focused on the FPF themselves, but some studies included sites surrounding the dam (Fig. 6b). One important finding is that upstream passage received greater research effort than downstream passage (Fig. 6c); for each study assessing downstream passage, eight focused on upstream passage (1:8 ratio). Most studies focused on fish assemblages (Fig. 6d), and population-level studies investigated 60 different species, of which $42 \%$ were migratory and 58\% non-migratory. Migratory fishes were more frequently investigated than non-migratory fishes, especially Prochilodus lineatus, Pimelodus maculatus, Salminus brasiliensis, Megaeporinus elongatus and Piaractus mesopotamicus (Tab. 2). Among non-migratory species, frequent target-species were Leporinus friderici, Hypostomus sp., Schizodon borellii and Schizodon nasutus. Across all studies, P. lineatus and P. maculatus were the most frequently investigated species (Tab. 2).

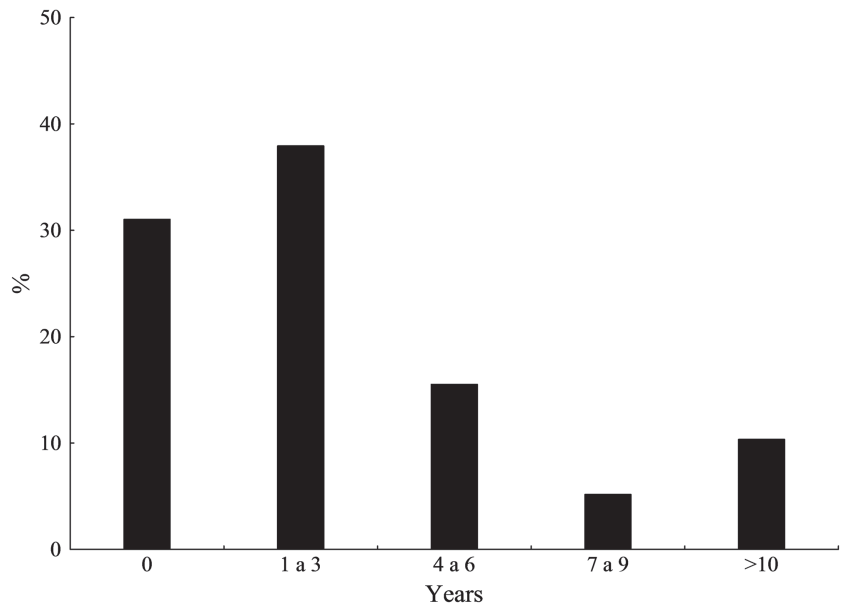

Fig. 5. Time interval (classes) between the beginning of operation of the fish passage and its first evaluation.

Studies addressed mainly questions of efficiency (62\%), followed by consequence (20\%) and mechanism (16\%); very few studies (2\%) focused on physiology (Fig. 7a). Efficiency questions were consistently frequent over the years, while questions about mechanism were investigated sporadically, especially in years of high scientific production associated with the two symposia (Fig. 7b). Questions of consequence and physiology remained few in number in all years.

\section{Discussion}

Our study provided quantitative evidence that FPF in South America have received substantial research attention, since our investigation retrieved 80 independent studies. This effort, however, was unevenly distributed over time. Even though FPF have been constructed since the beginning of the $20^{\text {th }}$ century (Agostinho et al., 2007a), most studies occurred in the last decade (2004-2014). Relatively few articles were published each year, and there was no temporal trend of increase or decrease. In addition, research effort appears to be unbalanced, since it was restricted to relatively 

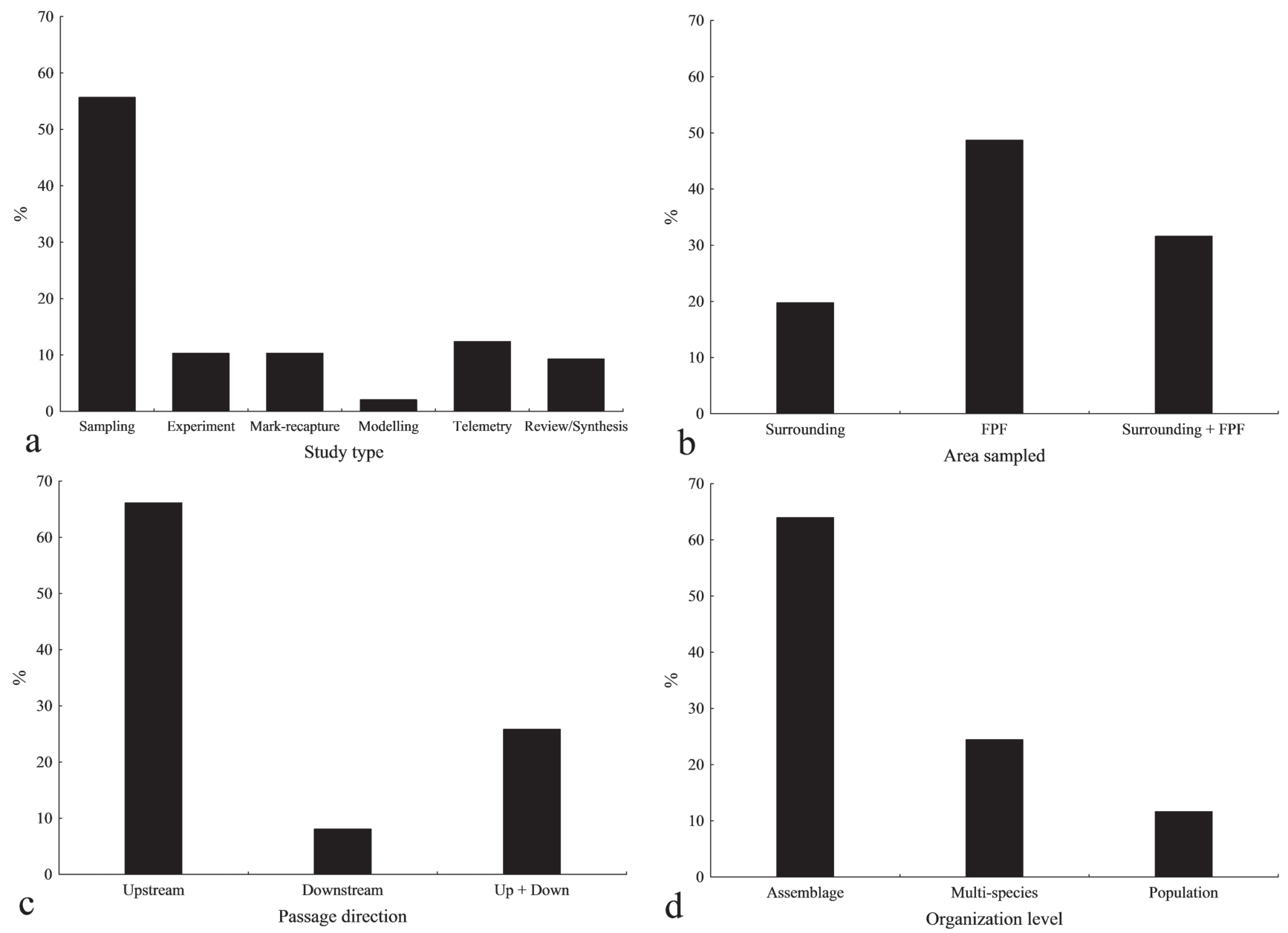

Fig. 6. Profile of studies that investigated fish passage facilities in South America. a. type of study; b. area sampled; c. passage direction; $\mathbf{d}$. level of biotic organization.

Tab. 2. Migratory and non-migratory fish species retrieved from studies that investigated fish passage facilities and nearby sites. These species were recorded from population-level studies (see Fig. 6d). $\mathrm{N}=$ number of studies.

\begin{tabular}{|c|c|}
\hline Species & $\mathbf{N}$ \\
\hline \multicolumn{2}{|l|}{ Migratory } \\
\hline Prochilodus lineatus & 23 \\
\hline Pimelodus maculatus & 13 \\
\hline Salminus brasiliensis & 11 \\
\hline Megaleporinus elongatus & 10 \\
\hline Piaractus mesopotamicus & 9 \\
\hline Pseudoplatystoma corruscans & 7 \\
\hline Megaleporinus obtusidens, Pterodoras granulosus & 5 \\
\hline Megaleporinus reinhardti, Salminus hilari, Prochilodus costatus & 4 \\
\hline Megaleporinus macrocephalus, Pseudoplatystoma fasciatum, Rhinelepis aspera, Zungaro zungaro & 3 \\
\hline Hemisorubim platyrhynchos, Leporinus sp., Rhaphiodon vulpinus, Zungaro jahu, Sorubim lima & 2 \\
\hline Pimelodus ornatus, Pinirampus pirinampu, Pseudoplatystoma reticulatum, Brycon hilari, Salminus franciscanus & 1 \\
\hline \multicolumn{2}{|l|}{ Non-migratory } \\
\hline Leporinus friderici & 7 \\
\hline Hypostomus sp., Schizodon borellii, Schizodon nasutus & 3 \\
\hline Astyanax sp., Piabarchus stramineus, Leporinus octofasciatus, Metynnis maculatus, Myleus tiete, Oxydoras knerii, Pimelodus sp., Schizodon intermedius & 2 \\
\hline $\begin{array}{l}\text { Pimelodus ornatus, Ageneiosus brevifilis, Apareidon affinis, Astyanax aff. fasciatus, Astyanax altiparanae, Astyanax fasciatus, Auchenipterus nuchalis, } \\
\text { Catathyridium jenynsii, Cichla kelberi, Cyphocharax santacatarinae, Geophagus brasiliensis, Hoplias malabaricus, Leporinus acutidens, Oligosarcus } \\
\text { aff. jenynsii, Pimelodus absconditus, Pimelodus clarias, Iheringichthys labrosus, Pimelodus albicans, Rhamdia quelen, Rhinodoras dorbignyi, } \\
\text { Schizodon knerii, Schizodon sp., Steindachnerina insculpta }\end{array}$ & 1 \\
\hline
\end{tabular}




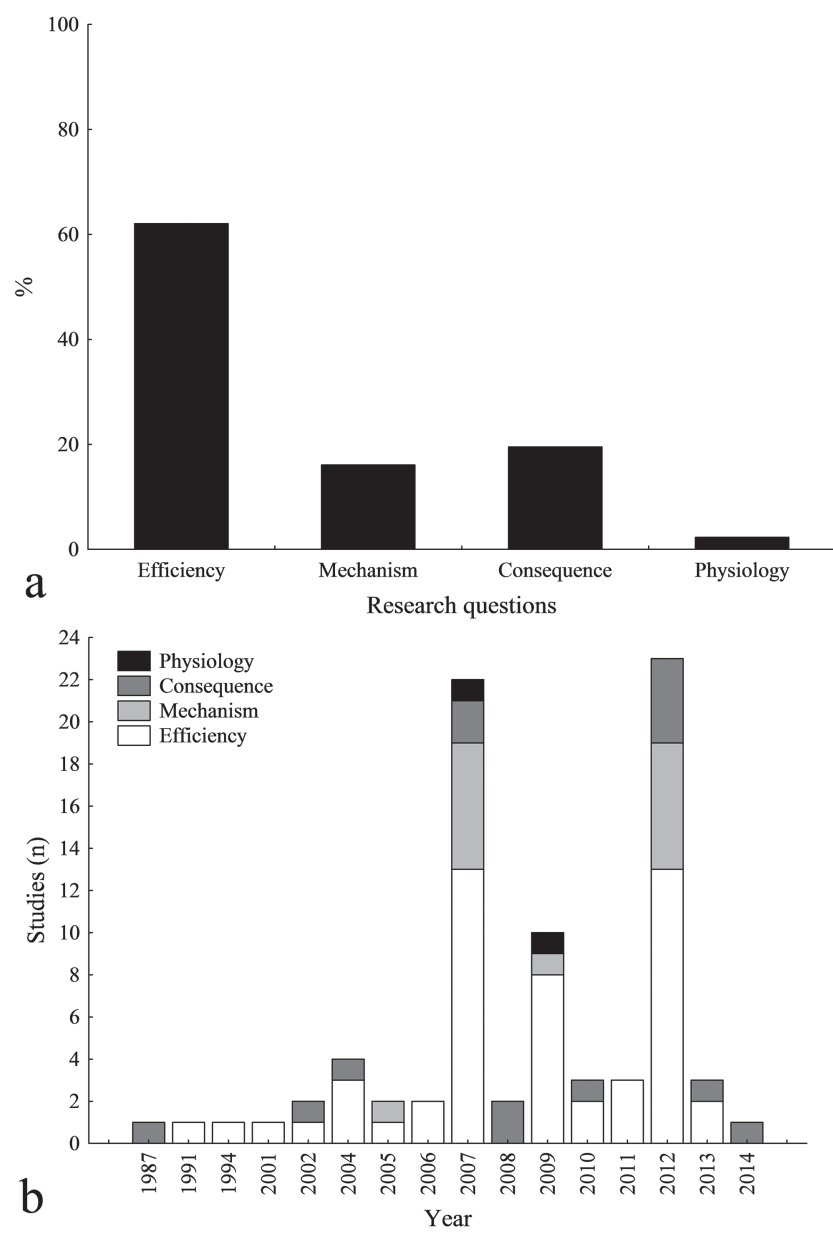

Fig. 7. Research questions addressed by studies, partitioned into categories sensu Roscoe, Hinch (2010). a. proportion of studies that addressed each research question; b. numeric distribution over the years.

few FPF ( $n=25$, mainly ladders) and biased towards specific topics. In particular, studies focused predominantly on the FPF themselves, addressing questions related to passage efficiency (i.e., upstream passage) and rarely touching on conservation issues. This scenario indicates that the role of FPF in restoring river function and improving conservation remains poorly known, in accordance with claims from past investigations (e.g., Agostinho et al., 2002, 2011; Pelicice, Agostinho, 2012; Pompeu et al., 2012). Such uncertainty may lead to inappropriate management decisions.

Studied facilities were distributed in different rivers of South America, but most are located in the Paraná River basin - where hundreds of dams regulate the flow of major river systems (Agostinho et al., 2016). Ladders were the most common fishways in our investigation, although other types have also been recorded. Historically, ladders were among the first facilities designed to assist salmonid migration (Katapodis, Williams, 2012). Due to their utility in particular hydraulic conditions (e.g., high flow and discharge), manageable engineering aspects and lower costs, they gained popularity and became the main fishway technology in the world (Agostinho et al., 2007a). These aspects may explain why they are so popular in South America.

One important finding is that FPF were installed predominantly in specific spatial contexts, i.e., major rivers and upper reaches of the basin. We also recorded FPF in small dams, but the majority is located in large dams. These patterns may be related to the common assumption that large dams cause stronger impacts, and that fish must reach headwaters to spawn. This is curious, however, because small dams also impede migratory movements (Cooney, Kwak, 2013), and dams currently regulate upper, middle and lower reaches of all river basins in the continent (Agostinho et al., 2016). More distressing is the fact that facilities are installed in contexts where connectivity to upstream and downstream reaches is severely limited. For example, all studied facilities have other dams located upstream or downstream, and many of these adjacent dams lacked FPF. These scenarios are in disagreement with the primary intention of fishways, i.e., to restablish migratory routes along the river continuum to allow recruitment and natural population dynamics (Agostinho et al., 2007a; Pompeu et al., 2012). Therefore, considering that most FPF are located in upper reaches, and that many facilities are isolated, we conclude that systematic planning (basin-scale) has not guided the installation of FPF in South America. Indeed, other reasons have determined the installation of fishways, such as legal constraints, social demands or logistical/ financial reasons (Agostinho et al., 2007a). This scenario may explain why some facilities lead fish to impoverished environments or may cause additional impacts (e.g., Pelicice, Agostinho, 2008; Pompeu et al., 2012). In principle, specific technical studies should determine the need for a FPF, based on previous assessments at the watershed scale (Agostinho et al., 2007a; Pompeu et al., 2012).

Most studies that evaluated FPF in South America were published in the last decade (2004-2014). A global-scale research survey also observed this trend (Roscoe, Hinch, 2010), indicating that fishway function has attracted attention only recently. High scientific publications in South America occurred in specific years. Most publications appeared during 2007 and 2012, when Neotropical Ichthyology published two special volumes dedicated to the subject (v. 5 and v. 10, both International Symposia on Fish Passages in South America). Therefore, future scientific production will probably depend on external motivation (e.g., International Conferences, financial incentives), especially if relevant data is held in grey literature (e.g., thesis, reports). It is important to emphasize that our study was extensive and probably gathered all relevant and accessible literature, but there might be valuable data in unpublished reports with restricted access. The publication of this literature must be encouraged, especially because we know little about its extent.

Research effort was unbalanced and concentrated on a limited group of facilities, located mainly in the Paraná and Tocantins river basins. Special attention has been devoted 
to the ladders at Lajeado, Peixe Angical, Igarapava and Porto-Primavera dams, the lift at Santa Clara dam, and the Canal da Piracema at Itaipu. This pattern is probably related to the focus of specific research groups and universities, which elected these fishways as study models. On the other hand, some FPF remain barely studied, such as those at Funil, Yacyreta and Canoas I and II. Other facilities are likely to exist that have not been studied; in fact, Pompeu, Martinez (2005) mentioned the existence of 50 ladders in South America. This information indicates that the number of studied facilities is low compared to the number installed. The fact that FPF are trivialized among managers (Agostinho et al., 2007a), which understand these facilities as efficient tools, must explain the paucity of investigations. Facilities are commonly installed without sound ecological information, and monitoring is absent or insufficient (Pompeu et al., 2012). Our literature survey, for example, found only post-installation studies, indicating that the decisions to build FPF are not typically based on a priori empirical assessments. In addition, the first evaluation of new FPF is usually delayed. The mean time elapsed between the beginning of the operation and evaluation was 3.3 years, but it reached decades in some cases. Older facilities tend to experience longer delays, probably because recent FPF are subjected to state laws, greater control by environmental agencies and social vigilance (Agostinho et al., 2007a). Delayed research prevents the assessment of management success, malfunctioning (e.g., selectivity, attraction; Agostinho et $a l ., 2007 \mathrm{a})$ and impacts (e.g., predation, ecological traps, source-sink, loss of genetic diversity; McLaughlin et al., 2012; Pelicice et al., 2015). In this context, fishways should be evaluated immediately after installation, older facilities should be regularly monitored, and results disseminated among researchers, managers and society.

Our investigation revealed that studies typically employ field sampling to evaluate passage efficiency focused on the fishway itself. This approach restricts understanding and leaves key questions unanswered, e.g., post-passage migration, spawning, recruitment, downstream passage and migration, and population persistence in the long-term (Agostinho et al., 2007b; Kraabol et al., 2009; Agostinho et al., 2011; Pompeu et al., 2012; Pelicice et al., 2015). For example, many species recorded inside the facility may not be able to complete passage, or may not reach critical habitats upstream. In this case, studies that use telemetry (e.g., Hahn et al., 2007), mark-recapture (e.g., Antonio et al., 2007) or evaluate the distribution of critical habitats (e.g., Pelicice, Agostinho, 2008) are essential to answer these questions.

One important aspect is the strong research bias toward upstream migration, which is probably inspired by the common assumption that safe upstream passage equals successful management (Agostinho et al., 2011; Pompeu et al., 2012). Migratory fishes in South America are potadromous, performing multiple upstream and downstream displacements throughout their life cycle (Carolsfeld et al., 2003; Godinho, Kynard, 2008). Lack of consideration for downstream movements and other post-passage issues, therefore, prevents inferences about management success. We cannot neglect the fact that all studies that investigated downstream passage found severe limitations, for both adult and young fish (Agostinho et al., 2007b; Lopes et al., 2007; Pelicice, Agostinho, 2008; Agostinho et al., 2011; Suzuki et al., 2011; Pelicice, Agostinho, 2012; Britto, Carvalho, 2013; Pelicice et al., 2015). For example, studies conducted at Lajeado and Peixe Angical fish ladders, Tocantins River, showed that downstream passage is negligible on a yearly basis. The average ascending:descending ratio was 1508:1 (Lajeado) and 644:1 (Peixe Angical), and many species performed only upward movements (Agostinho et al., 2011; Pelicice, Agostinho, 2012). As one-way passage can cause additional disturbance to fish populations (Pelicice, Agostinho, 2008; Britto, Carvalho, 2013; Pelicice et al., 2015), it is crucial that future evaluations include greater spatial scales and broader issues, beyond the FPF (Kraabol et al., 2009), and take population recruitment and persistence as the central management goal (Pompeu et al., 2012).

Regarding research questions (sensu Roscoe, Hinch, 2010), most studies addressed efficiency questions, i.e., issues related to fish passage, such as abundance and species composition within the fishway (e.g., Bowen et al., 2006; Makrakis et al., 2007a; Pompeu, Martinez, 2007), or the proportion of fish ascending and descending the facility (e.g., Agostinho et al., 2007d; Fernandez et al., 2007a; Makrakis et al., 2010). A smaller number addressed mechanism questions, which investigated how passage is affected by operation (e.g., Pompeu, Martinez, 2005), environmental variables (e.g., Fernandez et al., 2007b; Pereira-Assis et al., 2009a), and swimming ability (e.g., Santos et al., 2007; Assumpção et al., 2012; Santos et al., 2012). The fact that just a few papers addressed physiology and consequence questions is more troubling because these approaches provide essential information for management plans; efficiency and mechanism questions cannot, alone, determine management success and the impact of FPF on conservation. We emphasize that these research questions are complementary, so all must receive balanced attention. While some address small-scale and refined issues (e.g., passage efficiency, swimming ability), others address topics more related to management success (e.g., migration continuity and recruitment).

Studies that evaluated physiology and consequence questions investigated the effects of FPF on genetic diversity (e.g., Lopes et al., 2007; Ramos et al., 2012), predation pressure (e.g., Agostinho et al., 2012), and recruitment (e.g., Agostinho et al., 2004; Maia et al., 2007; Pelicice, Agostinho, 2008; Suzuki et al., 2013; Pelicice et al., 2015). Some of these studies, however, were literature reviews, syntheses or were based on secondary data. Purely empirical investigations were rare and did not evaluate 
whether management enhanced recruitment. Different factors may explain why physiology and consequence questions have been neglected. For example, hydropower companies usually fund monitoring programs, and are motivated exclusively by legal requirements; consequently, assessments rely on easily measured variables, such as upstream passage. The lack of clear conservation goals also leads to superficial evaluations, where the number of ascending fish is used as proxy of management success. Another bias is the prevailing assumption that FPF are efficient when they allow upstream migration, which puts heavy weight on upstream passage. In this case, the concept of successful passage must be replaced by the concept of successful management, where population persistence becomes the central goal (Pompeu et al., 2012). Another problem is that research is discontinuous and not systematized. Many FPF were studied just once, and longterm data are unavailable; research is commonly based on simple metrics (e.g., fish abundance and composition within the fishway), since studies on recruitment are expensive and more complex, involving different variables and wide spatial-temporal scales. In addition, each study investigated a single FPF (with few exceptions), providing little insight for basin-scale management.

Given the growing demand for electricity in South America, rivers have been progressively targeted for hydropower development (Agostinho et al., 2016; Less et al., 2016; Winemiller et al., 2016). Fluvial ecosystems are increasingly vulnerable to river regulation and impoundments, and FPF will continue to be installed with the intent of mitigating impacts. However, controversies and skepticism about their conservation role is growing (e.g., Agostinho et al., 2002, 2007a; Oldani et al., 2007; McLaughlin et al., 2012; Pompeu et al., 2012; Pelicice et al., 2015; Kemp, 2016), and the present study revealed that we have limited understanding about the functioning, management success and conservation value of fishways in South America. We hope that our study will guide future research to take place in a broader context, considering issues that range from fish passage efficiency to recruitment and population persistence. This information will allow better decisions concerning the installation of new facilities, and will clarify whether FPF can play a positive role in the conservation of Neotropical fish diversity.

\section{Acknowledgments}

We thank Mônica P. Araújo (UFRJ, PPGCiac) for drawing Fig. 1. We thank Universidade Federal do Tocantins, Núcleo de Estudos Ambientais (Neamb) and Programa de Pós-Graduação em Biodiversidade, Ecologia e Conservação (previous Ecologia de Ecótonos) for providing necessary conditions and infrastructure. $\mathrm{CNPq}$ provided a scholarship for NAL and research grants for FMP and AAA. FAPEMIG provided research grant for PSP. We also thank three anonymous reviewers for their valuable comments.

\section{References}

Agostinho AA, Gomes LC, Fernandez DR, Suzuki HI. Efficiency of fish ladders for Neotropical ichthyofauna. River Res Applic. 2002; 18:299-306.

Agostinho AA, Gomes LC, Suzuki HI, Júlio Junior HF. Migratory fish from the upper Parana river basin, Brazil. In: Carolsfeld J, Harvey B, Ross C, Baer A, editors. Migratory Fishes of South America: Biology, Fisheries and Conservation Status. Victoria: World Fisheries Trust, the World Bank and the International Development Research Centre; 2003. p.19-99.

Agostinho AA, Gomes LC, Latini JD. Fisheries management in Brazilian reservoirs: Lessons from/for South America. Interciencia. 2004; 29(6):334-38.

Agostinho AA, Gomes LC, Pelicice FM. Ecologia e Manejo de Recursos Pesqueiros em Reservatórios do Brasil. Maringá: Eduem; 2007a.

Agostinho AA, Marques EE, Agostinho CS, Almeida DA, Oliveira RJ, Melo JRB. Fish ladder of Lajeado Dam: migrations on one-way routes? Neotrop Ichthyol. 2007b; 5(2):121-30.

Agostinho AA, Agostinho CS, Pelicice FM, Marques EE. Fish ladders: safe fish passage or hotspot for predation? Neotrop Ichthyol. 2012; 10(4):687-96.

Agostinho AA, Gomes LC, Santos NCL, Ortega JCG, Pelicice FM. Fish assemblages in Neotropical reservoirs: Colonization patterns, impacts and management. Fish Res. 2016; 173(1):26-36.

Agostinho CS, Agostinho AA, Pelicice FM, Marques EE. Selectivity of fish ladders: a bottleneck in Neotropical fish movement. Neotrop Ichthyol. 2007c; 5(2):205-13.

Agostinho CS, Pereira CR, Oliveira RJ, Freitas IS, Marques EE. Movements through a fish ladder: temporal patterns and motivations to move upstream. Neotrop Ichthyol. 2007d; 5(2):161-67.

Agostinho CS, Pereira-Assis CR, Oliveira RJ. Seletividade no ingresso e ascensão de peixes na escada de Peixe Angical. In: Agostinho CS, Pelicice FM, Marques EE, editors. Reservatório de Peixe Angical: bases ecológicas para o manejo da ictiofauna. São Carlos: Rima; 2009. p.137-148.

Agostinho CS, Pelicice FM, Marques EE, Soares AB, Almeida DAA. All that goes up must come down? Absence of downstream passage through a fish ladder in a large Amazonian river. Hydrobiol. 2011; 675(1):1-12.

Alves CBM. Evaluation of fish passage through the Igarapé Dam fish ladder (rio Paraopeba, Brazil), using marking and recapture. Neotrop Ichthyol. 2007a; 5(2):233-36.

Alves CBM, Silva LGM, Godinho AL. Radiotelemetry of a female jaú, Zungaro jahu (Ihering, 1898) (Siluriformes: Pimelodidae), passed upstream of Funil Dam, rio Grande, Brazil. Neotrop Ichthyol. 2007b; 5(2):229-32.

Alves CBM. A ictiofauna e a escada experimental para peixes do Rio Paraopeba - UTE Igarapé, bacia do rio São Francisco (Minas Gerais). In: Lopes, JM, Silva FO, editors. Transposição de peixes. Belo Horizonte: Cemig; 2012. p.5975. (Série Peixe Vivo; 1). 
Antonio RR, Agostinho AA, Pelicice FM, Bailly D, Okada EK, Dias JHP. Blockage of migration routes by dam construction: can migratory fish find alternative routes? Neotrop Ichthyol. 2007; 5(2):177-84.

Arcifa MS, Esguícero ALH. The fish fauna in the fish passage at the Ourinhos Dam, Paranapanema River. Neotrop Ichthyol. 2012; 10(4):715-22.

Assumpção L, Makrakis MC, Makrakis S, Wagner RL, Silva PS, Lima AF, Kashiwaqui EAL. The use of morphometric analysis to predict the swimming efficiency of two Neotropical longdistance migratory species in fish passage. Neotrop Ichthyol. 2012; 10(4):797-804.

Baigún CRM, Nestler JM, Oldani NO, Goodwin RA, Weber LJ. Can north american fish passage tools work for South american migratory fishes? Neotrop Ichthyol. 2007; 5(2):109-19.

Baigún CRM, Nestler JM, Minotti P, Oldani N. Fish passage system in an irrigation dam (Pilcomayo River basin): When engineering designs do not match ecohydraulic criteria. Neotrop Ichthyol. 2012; 10(4):741-50.

Bastos LP, Silva AS, Netto OSM, Duarte J, Belz CE, Ota JJ, Borges PD, Leitão FHM, Cardoso CG. Avaliação da eficiência da escada de peixes da Usina hidrelétrica Ilha dos Pombos. In: XVIII Simpósio Brasileiro de Recursos Hídricos. Campo Grande: Acqua Consultoria; 2009.

Bizzotto PM, Godinho AL, Vono V, Kynard B, Godinho HP. Influence of seasonal, diel, lunar, and other environmental factors on upstream fish passage in the Igarapava Fish Ladder, Brazil. Ecol Freshw Fish. 2009; 18(3):461-72.

Borghetti JR, Nogueira VSG, Borghetti NRB, Canzi C. The fish ladder at the Itaipu Binacional hydroelectric complex on the Paraná River, Brazil. Regul River. 1994; 9(2):127-30.

Bowen MD, Marques S, Silva LGM, Vono V, Godinho HP. Comparing on site human and video counts at Igarapava fish ladder, Southeastern Brazil. Neotrop Ichthyol. 2006; 4(2):291-94.

Braga ALC, Silva MOB, Hojo RES, Sousa TM, Rezende GF. Fish passage through the fishway system on Risoleta Neves Dam Power Plant in Doce River, MG. In: I Simpósio Internacional de Transposição de Peixes da América do Sul. Lavras: Universidade Federal de Lavras; 2007.

Britto SGC, Carvalho D. Reproductive migration of fish and movement in a series of reservoirs in the Upper Parana River basin, Brazil. Fisheries Manag Ecol. 2013; 20(5):426-33.

Brown JJ, Limburg KE, Waldman JR, Stephenson K, Glenn EP, Juanes F, Jordaan A. Fish and hydropower on the U.S. Atlantic coast: failed fisheries policies from half-way technologies. Conserv Lett. 2013; 6(4):280-86.

Carolsfeld J, Harvey B, Ross C, Baer A, editors. Migratory Fishes of South America: Biology, Fisheries and Conservation Status. Victoria: World Fisheries Trust, the World Bank and the International Development Research Centre; 2003.

Casali RCV, Vono V, Godinho HP, Luz RK, Bazzoli N. Passage and reproductive activity of fishes in the Igarapava fish ladder, Grande River, Southeastern Brazil. River Res Applic. 2009; 26(2):157-65.
Clay CH. Desing fishways and other fish facilities. $2^{\text {nd }}$ Edition. Boca Raton: Lewis Publishers; 1995.

Cooney PB, Kwak TJ. Spatial extent and dynamics of dam impacts on tropical island freshwater fish assemblages. BioSci. 2013; 63(3):176-90.

Duarte BAF, Ramos ICR, Santos HA. Reynolds shear-stress and velocity: positive biological response of Neotropical fishes to hydraulic parameters in a vertical slot fishway. Neotrop Ichthyol. 2012; 10(4):813-19.

Esguícero ALH, Arcifa MS. Fragmentation of a Neotropical migratory fish population by a century-old dam. Hydrobiologia. 2010; 638(1):41-53.

Fernandez DR, Agostinho AA, Bini LM. Selection of an experimental fish ladder located at the dam of the Itaipu Binacional, Paraná river, Brazil. Braz Arch Biol Technol 2004; 47(4):579-86.

Fernandez DR, Agostinho AA, Bini LM, Pelicice FM. Diel variation in the ascent of fishes up an experimental fish ladder at Itaipu Reservoir: fish size, reproductive stage and taxonomic group influences. Neotrop Ichthyol. 2007a; 5(2):215-22.

Fernandez DR, Agostinho AA, Bini LM, Gomes LC. Environmental factors related to entry into and ascent of fish in the experimental ladder located close to Itaipu Dam. Neotrop Ichthyol. 2007b; 5(2):153-60.

Fontes Júnior HM, Castro-Santos T, Makrakis S, Gomes LC, Latini JD. A barrier to upstream migration in the fish passage of Itaipu Dam (Canal da Piracema), Paraná River basin. Neotrop Ichthyol. 2012a; 10(4):697-704.

Fontes-Júnior HM, Gomes LC, Makrakis S, Makrakis MC, Latini JD, Castro-Santos T, Domingues WM, Watanabe AL. Temporal variations in the ichthyofauna of the Canal da Piracema: is there a clear pattern in the movement of migratory fish? In: II Simpósio Internacional de Transposição de Peixes da América do Sul. Toledo: Universidade Estadual do Oeste do Paraná; 2012b.

Freeman MC, Pringle CM, Greathouse EA, Freeman BJ. Ecosystem-level consequences of migratory faunal depletion caused by dams. Am Fish Soc Symp. 2003; 35:255-66.

Freitas IS, Marques EE, Melo JRB, Araujo ES, Pinto MDS. Composição e abundância do ictioplâncton na escada de Peixe Angical e suas imediações. In: Agostinho CS, Pelicice FM, Marques EE, editors. Reservatório de Peixe Angical: bases ecológicas para o manejo da ictiofauna. São Carlos: Rima; 2009. p.159-164.

Godinho HP, Godinho AL, Formagio PS, Torquato VC. Fish ladder efficiency in a southeastern Brazilian river. Cienc Cult. 1991; 43(1):63-67.

Godinho AL, Silva Z, Silva MOB, Braga ALC. Influence of abiotic factors on fish passage at the Funil Fish Lift, Grande River, Brazil. In: Pompeu PS, Santos HA, Alves CBM, editors. Simpósio Internacional de Transposição de Peixes da América do Sul. Lavras: Universidade Federal de Lavras; 2007.

Godinho AL, Kynard B. Migratory fishes of Brazil: life history and fish passage needs. River Res Applic. 2008; 25(6):702-12. 
Godinho HP, Vono V, Godinho AL. Metodologia para o planejamento, implantação, definição de objetivos e monitoramento de sistemas de transposição de peixes pela Cemig. In: Lopes, JM, Silva FO, editores. Transposição de peixes. Belo Horizonte: Cemig; 2012. p.14-17. (Série Peixe Vivo, 1).

Godoy MP. A escada de peixes de Cachoeira das Emas, Rio Mogi Guassu, Estado de São Paulo, Brasil. Comum Mus Ciênc Tecnol, Sér Zool. 1987; 43:139-51.

Hahn L, English K, Carosfeld J, Silva LGM, Latini JD, Agostinho AA, Fernandez DR. Preliminary study on the application of radio-telemetry techniques to evaluate movements of fish in the lateral canal at Itaipu Dam, Brazil. Neotrop Ichthyol. 2007; 5(2):103-08.

Hahn L. Deslocamento de peixes migradores no rio Uruguai e no sistema misto de migração da barragem de Itaipu. [PhD Thesis]. Maringá, PR: Universidade Estadual de Maringá; 2007.

Hoeinghaus DJ, Agostinho AA, Gomes LC, Pelicice FM, Okada EK, Latini JD, Kashiwaqui EAL, Winemiller KO. Effects of river impoundment on ecosystem services of large tropical rivers: embodied energy and market value of artisanal fisheries. Conserv Biol. 2009; 23(5):1222-31.

Katapodis C, Williams JG. The development of fish passage research in a historical context. Ecol Eng. 2012; 48:8-18.

Kemp PS. Meta-analyses, metrics and motivation: mixed messages in the fish passage debate. River Res Applic. 2016; 32(10):2116-24.

Kraabol M, Johnsen SI, Museth J, Sandlund OT. Conserving iteroparous fish stocks in regulated rivers: the need for a broader perspective! Fish Manag Ecol. 2009; 16(4):337-40.

Kusma CM, Ferreira FW. Mecanismo de transposição de peixes de pequena central hidrelétrica. Cienc Rural. 2009; 40(1):8994.

Lees AC, Peres CA, Fearnside PM, Schneider M, Zuanon JAS. 2016. Hydropower and the future of Amazonian biodiversity. Biodivers Conserv. 2016; 25(3):451-66.

Lopes CM, Almeida FS, Orsi ML, Britto SGC, Sirol RN, Sodré LMK. Fish passage ladders from Canoas Complex - Paranapanema River: evaluation of genetic structure maintenance of Salminus brasiliensis (Teleostei: Characiformes). Neotrop Ichthyol. 2007; 5(2):131-38.

Lopes JM, Silva FO. Metodologia para o planejamento, implantação, definição de objetivos e monitoramento de sistemas de transposição de peixes pela Cemig. In: Lopes JM, Silva FO, editors. Transposição de peixes. Belo Horizonte: Cemig; 2012. p.19-33. (Série Peixe Vivo, 1).

Maia BP, Ribeiro SMF, Bizzotto PM, Vono V, Godinho HP. Reproductive activity and recruitment of the yellow-mandi Pimelodus maculatus (Teleostei: Pimelodidae) in the Igarapava Reservoir, Grande River, Southeast Brazil. Neotrop Ichthyol. 2007; 5(2):147-52.

Makrakis S, Makrakis MC, Wagner RL, Dias HJP, Gomes LC. Utilization of the fish ladder at the Engenheiro Sergio Motta Dam, Brazil, by long distance migrating potamodromous species. Neotrop Ichthyol. 2007a; 5(2):299-306.
Makrakis MC, Miranda LE, Makrakis S, Xavier AMM, Fontes HM, Morlis WG. Migratory movements of pacu, Piaractus mesopotamicus, in the highly impounded Parana River. J Appl Ichthyol. 2007b; 23(6):700-04.

Makrakis S, Gomes LC, Makrakis MC, Fernandez DR, Pavanelli CS. The Canal da Piracema at Itaipu Dam as a fish pass system. Neotrop Ichthyol. 2007c; 5(2):185-95.

Makrakis S, Miranda LE, Gomes LC, Makrakis MC, Junior HMF. Ascent of Neotropical migratory fish in the Itaipu Reservoir fish pass. River Res Applic. 2010; 27(4):511-19.

Makrakis S, Makrakis MC, Kashiwaqui EAL, Assumpção L, Silva PS, Chlusewicz TV, Alves-Júnior D, Moraes KAS, Piana RN, Pini S, Tavares AF. Prior assessment of the Neotropical ichthyofauna to decision on construction of fishway. In: II Simpósio Internacional de Transposição de Peixes da América do Sul. Toledo: Universidade Estadual do Oeste do Paraná; 2012.

McLaughlin RL, Smyth ERB, Castro-Santos T, Jones ML, Koops MA, Pratt TC, Vélez-Espino LA. Unintended consequences and trade-offs of fish passage. Fish and Fish. 2013; 14(4):580-604.

Moretto A. Análise da eficiência da escada para peixes no Ribeirão Garcia no município de Blumenau. [Master Dissertation]. Blumenau, SC: Universidade Regional de Blumenau; 2005.

Okada EK, Agostinho AA, Gomes LC. Spatial and temporal gradients in artisanal fisheries of a large Neotropical reservoir, the Itaipu Reservoir, Brazil. Can J Fish Aquat Sci. 2005; 62(3):714-24.

Oldani N, Baigún C, Delfino R, Rodriguez R. Evaluación de los sistemas de transferencia para peces de la represa de Yacyretá Natura Neotrop. 2001; 32(2):87-100.

Oldani NO, Baigún CRM. Performance of a fishway system in a major South American dam on the Paraná River (ArgentinaParaguay). River Res Applic. 2002; 18(2):171-83.

Oldani NO, Baigún CRM, Nestler JM, Goodwin RA. Is fish passage technology saving fish resources in the lower La Plata River basin? Neotrop Ichthyol. 2007; 5(2):89-102.

Pelicice FM, Agostinho AA. Fish-passage facilities as ecological traps in large Neotropical rivers. Conserv Biol. 2008; 22(1):180-88.

Pelicice FM, Agostinho CS. Deficient downstream passage through fish ladders: the case of Peixe Angical Dam, Tocantins River, Brazil. Neotrop Ichthyol. 2012; 10(4):705-13.

Pelicice FM, Pompeu PS, Agostinho AA. Large reservoirs as ecological barriers to downstream movements of Neotropical migratory fish. Fish Fish. 2015; 16(4):697-715.

Pereira GJM, Pompeu PS. Fish passage at Funil Hydroeletric Power Plant fish lift. In: II Simpósio Internacional de Transposição de Peixes da América do Sul. Toledo: Universidade Estadual do Oeste do Paraná; 2012.

Pereira-Assis CR, Pereira PR, Agostinho CS, Oliveira RJ. Influência da vazão na atração e ascensão de peixes na escada de Peixe Angical. In: Agostinho CS, Pelicice FM, Marques EE, editors. Reservatório de Peixe Angical: bases ecológicas para o manejo da ictiofauna. São Carlos: Rima; 2009a. p.131-138. 
Pereira-Assis CR, Agostinho CS, Marques EE. Padrão temporal e motivação para ascensão da escada da UHE Peixe Angical. In: Agostinho CS, Pelicice FM, Marques EE, editors. Reservatório de Peixe Angical: bases ecológicas para o manejo da ictiofauna. São Carlos: Rima; 2009b. p.149-157.

Pereira-Assis CR. Monitoramento de peixes em escadas: contagem visual ou amostras com tarrafas? [Master Dissertation]. Porto Nacional, TO: Universidade Federal do Tocantins; 2010.

Pompeu PS, Ferreira VP, Silva HF, Martinez CB. Evaluation of downstream fish passage through Santa Clara Power Plant Dam, Minas Gerais, Brazil. In: V International Symposium on Ecohydraulics. Madrid: Universidad Politécnica de Cartagena (UPCT), Instituto Geológico y Minero (IGME); 2004.

Pompeu PS, Martinez CB. Estabelecimento da Regra Operativa de um Mecanismo de Transposição de Peixes do Tipo Elevador com Caminhão-Tanque. Rev Bras Rec Hídr. 2005; 10(4):31-42.

Pompeu PS, Martinez CB. Variações temporais na passagem de peixes no elevador da Usina Hidrelétrica de Santa Clara, Rio Mucuri, leste brasileiro. Rev Bras Zool. 2006; 23(2):340-49.

Pompeu PS, Martinez CB. Efficiency and selectivity of a trap and truck fish passage system in Brazil. Neotrop Ichthyol. 2007; 5(2):169-76.

Pompeu PS, Nogueira LB, Godinho HP, Martinez CB. Downstream passage of fish larvae and eggs through a small-sized reservoir, Mucuri River, Brazil. Zoologia. 2011; 28(6):739-46.

Pompeu PS, Agostinho AA, Pelicice FM. Existing and future challenges: the concept of successful fish passage in South America river research and applications. River Res Applic. 2012; 28(4):504-12.

Ramos JVB, Sodré LMK, Orsi ML, Almeida FS. Genetic diversity of the species Leporinus elongatus (Teleostei: Characiformes) in the Canoas Complex - Paranapanema River. Neotrop Ichthyol. 2012; 10(4):821-28.

Rodrigues RR, Godinho AL, Junho RAC, Pugh D, Kynard B. Influence of hydraulics on the upstream passage performance of Amazonian fishes in an experimental fishway. In: II Simpósio Internacional de Transposição de Peixes da América do Sul. Toledo: Universidade Estadual do Oeste do Paraná; 2012.

Roscoe DW, SG Rinch. Effectiveness monitoring of fish passage facilities: historical trends, geographic patterns and future directions. Fish Fish. 2010; 11(1):12-33.

Santos HA, Pompeu PS, Martinez CB. Swimming performance of the migratory Neotropical fish Leporinus reinhardti (Characiformes: Anostomidae). Neotrop Ichthyol. 2007; 5(2):139-46.

Santos HA, Martinez CB. Estudo da capacidade natatória de peixes neotropicais. In: Lopes, JM, Silva FO, editors. Transposição de peixes. Belo Horizonte: Cemig; 2012. p.133-170. (Série Peixe Vivo, 1).

Santos HA, Viana EMF, Pompeu PS, Martinez CB. Optimal swim speeds by respirometer: an analysis of three Neotropical species. Neotrop Ichthyol. 2012; 10(4):805-11.

Silva LGM, Nogueira LB, Maia BP, Resende LB. Fish passage post-construction issues: analysis of distribution, attraction and passage efficiency metrics at the Baguari Dam fish ladder to approach the problem. Neotrop Ichthyol. 2012a; 10(4):751-62.
Silva LGM. Parâmetros migratórios e transposição de curimbatás e mandis-amarelos no médio Rio Grande. In: Lopes, JM, Silva FO, editors. Transposição de peixes. Belo Horizonte: Cemig; 2012 b. p.111-131. (Série Peixe Vivo, 1).

Silva PS, Makrakis MC, Andrade FF, Assumpção L, Azevedo AV, Makrakis S, Dias JHP, Marques H. Downstream passage of fish eggs and larvae through the Porto Primavera fish ladder, Upper Paraná River, Brazil. In: II Simpósio Internacional de Transposição de Peixes da América do Sul. Toledo: Universidade Estadual do Oeste do Paraná; 2012c.

Souza DM, Silva Z, Silva MOB, Rezende GF, Nogueira LA. Monitoring fish fauna at Funil Hydroeletric Power Plant Fishway, Grande River, MG, Brazil. In: I Simpósio Internacional de Transposição de Peixes da América do Sul. Lavras: Universidade Federal de Lavras; 2007.

Souza DF, Britto SGC, Nogueira MG, Nobile AB, Ferrareze MF, Carvalho ED. 2012. A first evaluation of the passage mechanism after the filling up of Palmeiras Small Hydro Plants (SapucaíMirin River, Grande River basin - Brazil). In: II Simpósio Internacional de Transposição de Peixes da América do Sul. Toledo: Universidade Estadual do Oeste do Paraná; 2012.

Suzuki FM, Pires LV, Pompeu PS. Passage of fish larvae and eggs through the Funil, Itutinga and Camargos Reservoirs on the upper Rio Grande (Minas Gerais, Brazil). Neotrop Ichthyol. 2011; 9(3):617-22.

Suzuki FM, Zambaldi LP, Pompeu PS. Mapping The critical habitats for migratory species of the upper Grande River region, Minas Gerais State, Brazil. Appl Ecol Env Res. 2013; 11(4):645-59.

Volpato GL, Barreto RE, Marcondes AL, Moreira PSA, Ferreira MFB. Fish ladders select fish traits on migration - still a growing problem for natural fish populations. Mar Freshw Behav Phy. 2009; 42(5):307-13.

Vono V. Fish passage at the Igarapava fish ladder, River Grande, Brazil. In: International Congress on the Biology of Fish. Manaus; 2004.

Vono V, Godinho AL, Godinho HP. Fishway effect on the fishes in a Brazilian reservoir. In: I Simpósio Internacional de Transposição de Peixes da América do Sul. Lavras: Universidade Federal de Lavras; 2007.

Wagner RL, Makrakis S, Castro-Santos T, Makrakis MC, Dias JHP, Belmont RF. Passage performance of long-distance upstream migrants at a large dam on the Paraná River and the compounding effects of entry and ascent. Neotrop Ichthyol. 2012; 10(4):785-95.

Winemiller KO, McIntyre PB, Castello L, Fluet-Chouinard E, Giarrizzo T, Nam S, Baird IG, Darwall W, Lujan NK, Harrison I, Stiassny MLJ, Silvano RAM, Fitzgerald DB, Pelicice FM, Agostinho AA, Gomes LC, Albert JS, Baran E, Petrere Junior M, Zarfl C, Mulligan M, Sullivan JP, Arantes CC, Sousa LM, Koning AA, Hoeinghaus DJ, Sabaj M, Lundberg JG, Armbruster J, Thieme ML, Petry P, Zuanon J, Torrente Vilara G, Snoeks J, Ou C, Rainboth W, Pavanelli CS, Akama A, van Soesbergen A, Sáenz L. Balancing hydropower and biodiversity in the Amazon, Congo and Mekong. Science. 2016; 351(6269):128-29.

Submitted September 25, 2016

Accepted June 13, 2017 by Brian Sidlauskas 
